\title{
Particularities of Forming Desert Pastures Near Settlements of Southern Balkhash (Kazakhstan)
}

\author{
Kanaibek Kubenkulov ${ }^{*}$, Ashat Naushabaev', Niet Abdirahymov', \\ Bagdat Rustemov' ${ }^{1}$, Sultan Bazarbayev ${ }^{1}$ \\ ${ }^{1}$ Kazakh National Agrarian University, Abay Avenue 8, Almaty, 050010, Kazakhstan \\ * Corresponding author's e-mail: kem_707@mail.ru
}

\begin{abstract}
The results of field soil-and-geobotanical research study of the pastures near settlement Lepsy located in the desert area of the Almaty region are shown. The particularities of the climatic conditions for the formation of desert pastures in Southern Balkhash area are described. The characteristics of the plant cover of the pastures and the graybrown soils formed under them are provided. The effects of long unsystematic use of the pastures in the conditions of the growth of concentrated grazing areas near settlements on the degradation of the plant and soil covers have been identified, and four stages of degradation have been outlined by seven indicators. In determining the boundaries, the spectrometric characteristics of the surface of the pastures in the spectrum of near-infrared $(600-750 \mathrm{~nm})$, blue (400-500 nm), and red (500-600 nm) bands were used.
\end{abstract}

Keywords: degradation, pasture, dominant, soil, spectral brightness coefficient.

\section{INTRODUCTION}

The territory of the Almaty region features an extremely large variety of climatic conditions. It stretches from the snowy peaks of Khan-Tengri in the East to the mouth of the river Ili in the West, where over $2 / 3$ of its area is occupied by foothill semi-arid and arid pastures. Due to the establishment of new livestock breeding farms early in the second half of the last century and the redistribution of animals from these farms to the population due to the break-up in the nineties, the concentration of grazing animals near the settlements and stations of the farms dramatically increased, resulting in badly damaged grazing lands.

Currently, on the background of further aridization of the planet, the processes of natural grazing grasslands degradation have been developing most intensively. According to the official statistics, in the territory of the republic, there are 27.1 million hectares of downed (the last stage of degradation) grasslands, which is equal to $10 \%$ of the country's area.
The issues of using the pastures and recovering them from degradation were studied by the scientists of the Kazakh Research Institute of Livestock Breeding and Fodder Production [Zhambakin 1995; Torekhanov 2005; Alimaev et al. 2017], and by the scientists in foreign countries [UNDP/GM SGP/GEF OF "Farmer of Kazakhstan" 2007; Final report of Kazakhstan on UNCCD project Land Degradation Neutrality... 2018]. In the scale of the state, measures were taken to combat desertification [Strategic measures to combat desertification... 2015], and law about pastures was adopted [The law of the Republic of Kazakhstan dated February 20, 2017].

These research studies had local nature, and could not reveal the actual processes in such a variety of the soil-and-vegetation cover of the pastures in the republic. This article represents the materials of the field and laboratory studies on the effect of the intensity of grazing the cattle from settlements in the desert zone on the state of the pastures. 


\section{METHODS}

Field geobotanical work was performed in accordance with the existing instructions for performing botanical surveys of grasslands and pastures in the territory of Kazakhstan [Guidelines and methods of botanic-forage survey... 1969], and soil work - according to the guidelines for performing large-scale surveys of the lands in the Republic of Kazakhstan [Instruktsiya po provedeniyu krupnomasshtabnykh izyskanii zemel Respubliki Kazakhstan 1995]. Along with ground surveys for identifying and setting the boundaries of degradation of the used pastures, the methods of earth remote sensing (ERS) were used [Zakarin et al. 1999].

Field studies were performed on the plots preselected with the use of satellite images, using seven soil and plant indicators (Tables 1 and 2). The state of pasture vegetation was assessed by four degrees of degradation: 1 - weak, 2 - medium, 3 - severe, and 4 - very severe (failure).

\section{RESULTS AND DISCUSSION}

Soil and plant indicators were analyzed on the grassland plots near settlement Lepsy located in the desert area. The soils of the plot are represented by gray-brown soils formed in particularly harsh climatic conditions characterized as sharply continental and arid, which is typical for the inland deserts of the moderate band [Borovsky 1989; Faizov 1980; Lobova 1960].

Within the boundaries of the republic, the zone of gray-brown soils is a wide strip from $525 \mathrm{~km}$ wide in the West to $300-400 \mathrm{~km}$ wide in the central part, and sharply tapering (down to $50 \mathrm{~km}$ ) in the East from the Caspian coast to the BalkhashAlakul depression, occupying 61.8 million ha.

According to the information from the Lepsy weather station located at the altitude of $351 \mathrm{~m}$, the average annual temperature is $5.4^{\circ} \mathrm{C}$ that fluctuates between $24^{\circ} \mathrm{C}$ in July and $-16^{\circ} \mathrm{C}$ in January, with the absolute minimum and maximum of $-40^{\circ} \mathrm{C}$ and $+40^{\circ} \mathrm{C}$, respectively. The sum of effective temperatures is $2,800^{\circ}$. The dates of the last and the first frosts fall into the middle of the last decades of April and September. The average annual rainfall $(128 \mathrm{~mm})$ is distributed over the seasons $-23,26,16$ and $35 \%$, respectively. The snow cover with the height of $2 \mathrm{~cm}$ settles in November, gradually increasing to $10 \mathrm{~cm}$ by the end of December, and $14 \mathrm{~cm}$ in January, reaching its maximum $(17 \mathrm{~cm})$ in the first week of February, which indicates a small amount of snow in the territory. The depth of drenching does not exceed $0.6 \mathrm{~m}$. The reserve of productive moisture by the beginning of the spring vegetation in the top $0.5 \mathrm{~m}$ layer does not exceed $40 \mathrm{~mm}$ [Levitskaya 1973]. The north-Eastern winds blowing at the speed of $3-5 \mathrm{~m} / \mathrm{sec}$ alternate with the South-Eastern dry winds that sometimes reach great speed. This circumstance, with the insignificant rainfall in the summer months, along with the high temperatures, creates the conditions for a very low hydrothermal coefficient $(0.1-0.2)$. In the above-mentioned climatic conditions, gray-brown soils are formed under the stipa-sagebrush-ceratocarpus association with ephemerous plants.

For characterizing the soil of pastures, soil cuts were made in the second decade of October

Table 1. The effect of the degree of pasture degradation on biological indicators

\begin{tabular}{|c|c|c|c|c|}
\hline \multirow[b]{2}{*}{ Indicators } & \multicolumn{4}{|c|}{ Degree of degradation } \\
\hline & $\begin{array}{c}\text { very severe } \\
\text { IV degree, failure }\end{array}$ & severe, III degree & medium, II degree & $\begin{array}{c}\text { weak, I degree (back- } \\
\text { ground) }\end{array}$ \\
\hline Projective cover, \% & $6-8$ & $35-40$ & $40-45$ & $55-60$ \\
\hline $\begin{array}{l}\text { The name of the plant } \\
\text { community }\end{array}$ & $\begin{array}{l}\text { Ceratocarpus-sage- } \\
\text { brush }\end{array}$ & $\begin{array}{l}\text { sagebrush-ceratocar- } \\
\text { pus-stipa }\end{array}$ & $\begin{array}{l}\text { sagebrush-stipa-cera- } \\
\text { tocarpus }\end{array}$ & $\begin{array}{l}\text { stipa-sagebrush-cerato- } \\
\text { carpus with ephemerals }\end{array}$ \\
\hline $\begin{array}{l}\text { Species composition, } \\
\text { dominants }\end{array}$ & $\begin{array}{l}\text { ceratocarpus, blue- } \\
\text { grass, sagebrush }\end{array}$ & $\begin{array}{l}\text { sagebrush, ceratocar- } \\
\text { pus, stipa }\end{array}$ & $\begin{array}{l}\text { sagebrush, stipa-cera- } \\
\text { tocarpus }\end{array}$ & $\begin{array}{l}\text { stipa, sagebrush, } \\
\text { ceratocarpus, prostrate } \\
\text { summer cypress }\end{array}$ \\
\hline $\begin{array}{l}\text { Botanical composi- } \\
\text { tion, \% }\end{array}$ & $\begin{array}{l}\text { ceratocarpus } 45 \text {, sage- } \\
\text { brush } 20 \text {, bluegrass } 15 \\
\text { and others } 20\end{array}$ & $\begin{array}{l}\text { sagebrush } 50, \text { stipa } 20 \text {, } \\
\text { ceratocarpus } 30\end{array}$ & $\begin{array}{l}\text { sagebrush } 50, \text { stipa } 40 \text {, } \\
\text { ceratocarpus } 10\end{array}$ & $\begin{array}{l}\text { stipa } 40 \text {, sagebrush } 30 \text {, } \\
\text { ceratocarpus } 30 .\end{array}$ \\
\hline $\begin{array}{l}\text { Poisonous and un- } \\
\text { grazed species }\end{array}$ & $\begin{array}{l}\text { harmel peganum, single } \\
\text { bushes }\end{array}$ & $\begin{array}{l}\text { harmel peganum, single } \\
\text { bushes }\end{array}$ & $\begin{array}{l}\text { harmel peganum, single } \\
\text { bushes }\end{array}$ & $\begin{array}{l}\text { harmel peganum, single } \\
\text { bushes }\end{array}$ \\
\hline $\begin{array}{l}\text { The yield rate of the } \\
\text { pasture forage, hw/ha }\end{array}$ & 0.40 & 0.48 & 0.53 & 0.89 \\
\hline $\begin{array}{l}\text { Availability of grazing } \\
\text { lands }\end{array}$ & & & available & available \\
\hline
\end{tabular}


2018 on the leveled-out plain between the hills of the hilly-undulating elevation of the southern coast of Lake Balkhash. The land is a weakly degraded natural pasture. Vegetation is the following: stipa $-40 \%$, sagebrush $-30 \%$, and ceratocarpus $-30 \%$. The projective cover is $55-60 \%$. The surface of the soil is weakly fractured. The gray-brown soils in the studied area are characterized by a clearly pronounced structure of the profile with separated genetic horizons $\mathrm{A}, \mathrm{B}_{1}, \mathrm{~B}_{2}, \mathrm{BC}$, and $\mathrm{C}$. They are characterized by the following features of the morphological features:

- pale-brown $(10 \mathrm{YR} \% / 3)$, dry, weakly compacted, lumpy-powder-like, sandy-loam, radiculose humus horizon $(0-10 \mathrm{~cm})$;

- light-yellow-brown (10YR 6/4), dry, rather dense, sandy loam, weakly radiculose, lumpy-powder-like transition horizon $\mathrm{B}_{1}+\mathrm{B}_{2}$ $(10-62 \mathrm{~cm})$ with rare crystals of gypsum; and

- very pale-brown (10YR 7/3), fresh, weakly compacted, lumpy-powder-like, rarely-smallradiculose, sandy loam transition horizon BC $(62-82 \mathrm{~cm})$ that gradually transfers into very pale brown $\left(10 \mathrm{YR}^{7 / 4}\right)$ sandy parent rock (82 $\mathrm{cm}$ and deeper).

On the territory of the grazing lands, along with the full-profile gray-brown soils, up to $10 \%$ of the area are represented by weakly and slightly developed genera, which are widely spread on the hills with the relative height of $10-15 \mathrm{~m}$. Soil formation in these lands occurs in the conditions of macadam presence and close-lying crystalline rocks, the negative effect of which increases with approaching hilltops. In such plots under the sparse and stunted sagebrush vegetation, especially in the southern exposures, poorly and weakly developed soil is formed, where the thickness of the stone-free layer does not exceed 80 and $40 \mathrm{~cm}$, respectively. The grazing value of such sites is negligible.

Long haphazard year-round use (for over 60 years) of the territory to the North from settlement Lepsy as a natural pasture has resulted in degradation. The degree of degradation is significantly higher at the outskirts of the settlement and gradually decreases with the distance from it. It is clearly manifested in the state of the vegetation cover, both during on-ground surveys and from satellite images (Table 1).

The data in Table 1 show that with the growth of pastures degradation, the initial (background) stipa-sagebrush-ceratocarpus community is replaced with the sagebrush-stipa-ceratocarpus one (plots with the II degree), and with its further degradation (plots with the III degree) - with sagebrush-ceratocarpus-stipa, and in case of failure - with ceratocarpus-sagebrush community, i.e., pasture degradation results in changes in the species composition of the vegetation cover, replacing the best dominants (stipa) with the worst ones (ceratocarpus). This phenomenon is clearly marked in the projective covering, where it is reduced from $55-60 \%$ (in the background plot) to $6-8 \%$ (in the plot with the IV degree of degradation). It should be noted that in all degrees of degradation of the pastures vegetation cover, the presence and the composition of poisonous and ungrazed species remain constant. The changes in the botanical composition of the vegetation and their condition were manifested in the yield rate of the pasture forage. The growth of degradation reduces the yield rate from $0.89 \mathrm{hw} / \mathrm{ha}$ in the background plot up to $0.40 \mathrm{hw} / \mathrm{ha}$ in the plot with the IV degree of degradation.

The use of natural pastures, along with changes in vegetation cover, also influenced the state of the soil cover (Table 2).

The gray-brown, low-carbonate $\left(\mathrm{CO}_{2}\right.$ carbonates $1.5-3.0 \%$ ) sandy loamy (physical clay $13-19 \%)$ low humic $(0.66 \%)$ nonsaline (total salts $<0.20 \%$ ) soils of the pastures in the background area feature low content of available nitrogen $(\mathrm{Nlg}<30 \mathrm{mg} / \mathrm{kg})$, low content of phosphorus $(13 \mathrm{mg} / \mathrm{kg})$, and increased content of potassium $(350 \mathrm{mg} / \mathrm{kg})$. In the process of increasing pastures degradation, i.e., decreasing the share of stipa with the well-developed root system and increasing the load from the hooves of animals on the soil, the structure of the profile is disrupted. It is manifested in reducing the thickness of the humic horizon $\left(\mathrm{A}+\mathrm{B}_{1}\right)$ from $27 \mathrm{~cm}$ to $18 \mathrm{~cm}$ due to the loss of the silty particles of the surface layer, in the frequent occurrence of windy days in the dry seasons, and in increased density of horizon $\mathrm{B}_{1}$. It also affects the humus content in the soil, especially in the $0-10 \mathrm{~cm}$ layer, where its content reduces from $0.66 \%$ in the background plot to $0.39 \%$ in the plot with the III level of degradation. All this has eventually resulted in a small decrease in the absorption capacity of the soil from $5.1 \mathrm{mEq}$ to $4.8 \mathrm{mEq}$ per $100 \mathrm{~g}$ of soil. The effect of pastures degradation is more manifested by the reduced content of hydrolyzable nitrogen than mobile phosphorus. Degradation of pastures has no effect on the content of salts in the soil.

The changes in the vegetation and soil cover of degraded pastures are clearly visible in their spectral images (Figure 1). 
Table 2. The effect of the degree of pasture degradation on the structure, the composition, and the properties of gray-brown soil

\begin{tabular}{|c|c|c|c|c|c|c|}
\hline \multirow{2}{*}{\multicolumn{2}{|c|}{ Indicators }} & \multirow[b]{2}{*}{ Depth, cm } & \multicolumn{4}{|c|}{ Degree of degradation } \\
\hline & & & $\begin{array}{l}\text { very severe } \\
\text { (failure) } \\
\text { IV degree }\end{array}$ & $\begin{array}{l}\text { severe } \\
\text { III degree }\end{array}$ & $\begin{array}{l}\text { moderate } \\
\text { II degree }\end{array}$ & $\begin{array}{c}\text { weak } \\
\text { I degree } \\
\text { (background) }\end{array}$ \\
\hline \multicolumn{2}{|c|}{ The humus horizon thickness $\left(A+B_{1}\right), \mathrm{cm}$} & & - & 18 & 24 & 27 \\
\hline \multicolumn{2}{|c|}{ Humus content, \% } & $\begin{array}{c}0-10 \\
10-20 \\
20-30\end{array}$ & $\begin{array}{l}- \\
- \\
-\end{array}$ & $\begin{array}{l}0.39 \\
0.61 \\
0.52\end{array}$ & $\begin{array}{l}0.45 \\
0.86 \\
0.50\end{array}$ & $\begin{array}{l}0.66 \\
0.91 \\
0.50\end{array}$ \\
\hline \multicolumn{2}{|c|}{$\begin{array}{l}\text { The sum of the absorbed bases (mEq } \\
\text { per } 100 \mathrm{~g} \text { of soil) and their composition } \\
(\mathrm{Ca}, \mathrm{Mg}, \mathrm{Na}, \% \text { of the total) }\end{array}$} & $\begin{array}{c}0-10 \\
10-20 \\
20-30\end{array}$ & $\begin{array}{l}- \\
- \\
-\end{array}$ & $\begin{array}{l}4.8 ; 77.15 .7 \\
8.9 ; 91.4 .5 \\
6.0 ; 79.8 .13\end{array}$ & $\begin{array}{c}5.0 ; 78.14 .8 \\
9.8 ; 93.3 .4 \\
7.8 ; 78.9 .13 \\
\end{array}$ & $\begin{array}{l}5.1 ; 75.16 .9 \\
11.4 ; 93.3 .4 \\
7.2 ; 82.6 .12\end{array}$ \\
\hline \multicolumn{2}{|c|}{ The content of physical clay (\%) } & $\begin{array}{c}0-10 \\
10-20 \\
20-30\end{array}$ & $\begin{array}{l}- \\
- \\
-\end{array}$ & $\begin{array}{l}10.2 \\
17.8 \\
18.0\end{array}$ & $\begin{array}{l}12.1 \\
18.3 \\
16.6\end{array}$ & $\begin{array}{l}14.2 \\
18.5 \\
16.0\end{array}$ \\
\hline \multicolumn{2}{|c|}{ The content of water-soluble salts (\%) } & $\begin{array}{c}0-10 \\
10-20 \\
20-30\end{array}$ & $\begin{array}{l}- \\
- \\
-\end{array}$ & $\begin{array}{l}0.08 \\
0.09 \\
0.22\end{array}$ & $\begin{array}{l}0.08 \\
0.08 \\
0.21\end{array}$ & $\begin{array}{l}0.06 \\
0.07 \\
0.19\end{array}$ \\
\hline \multicolumn{2}{|c|}{$\mathrm{pH}$ of water suspension } & $\begin{array}{c}0-10 \\
10-20 \\
20-30\end{array}$ & $\begin{array}{l}- \\
- \\
-\end{array}$ & $\begin{array}{l}8.2 \\
8.2 \\
8.3 \\
\end{array}$ & $\begin{array}{l}8.0 \\
8.0 \\
8.2 \\
\end{array}$ & $\begin{array}{l}8.0 \\
8.0 \\
8.2 \\
\end{array}$ \\
\hline \multirow{2}{*}{$\begin{array}{l}\text { The content of } \\
\text { mobile nutrients } \\
\text { (mg/kg of soil) }\end{array}$} & $\mathrm{N}_{\text {hydr. }}$ & $\begin{array}{c}0-10 \\
10-20 \\
20-30\end{array}$ & $\begin{array}{l}- \\
- \\
-\end{array}$ & $\begin{array}{l}17.1 \\
15.6 \\
16.9\end{array}$ & $\begin{array}{l}24.7 \\
22.1 \\
21.1\end{array}$ & $\begin{array}{l}30.8 \\
28.0 \\
30.8\end{array}$ \\
\hline & $\mathrm{P}_{2} \mathrm{O}_{5}$ & $\begin{array}{c}0-10 \\
10-20 \\
20-30\end{array}$ & $\begin{array}{l}- \\
- \\
-\end{array}$ & $\begin{array}{l}17.7 \\
6.0 \\
3.1\end{array}$ & $\begin{array}{l}18.7 \\
6.0 \\
3.1\end{array}$ & $\begin{array}{c}20.1 \\
6.7 \\
3.8\end{array}$ \\
\hline
\end{tabular}

In contrast to the visual assessments of the pasture state, which are the basis for determining the boundaries between the degrees of degradation, determining the color of the surface of the pastures by measuring their optical properties allows obtaining real physical characteristics [Karmanov 1974]. Determining the state of the surface of the pastures using a ground-based spectrometer allows expressing the color numerically in the form of graphs that show the dependence of the reflectance on the wavelength. The data on the $\mathrm{x}$-axis show the wavelengths in the visible range $(400-750 \mathrm{~nm})$ of the spectrum, and on the $y$-axis - spectral brightness expressed as the spectral brightness coefficient (SBC) of the object at various wavelengths, which characterizes the structure of the light reflected by the surface.

Formation of the spectral composition of the pasture surface involves both the areas with open soil and the autumn state of the remaining vegetation, each having its own reflection spectra. Therefore, the data about the light beam reflected from the surface of the pastures, which is obtained by the spectrometer, are represented by many lines that vary depending on the wavelength.

The results of spectrometric studies of the pasture surface showed the presence of notable differences between land plots with various degrees of degradation. The reflectivity
(SBC) expressed in the near-infrared range $(600-750 \mathrm{~nm})$ of a weakly degraded plot represented by stipa-sagebrush-ceratocarpus community with rather good projective cover $(55-60 \%)$ was the highest $(0.20-0.30 \%)$, compared to other plots, especially with the very compacted plot $(0.10-0.15 \%)$ (Figure 2). A similar pattern is observed in the ranges of blue $(400-500 \mathrm{~nm})$ and red $(500-600 \mathrm{~nm})$ of the electromagnetic spectrum, which are $0.03-0.09 \%$ to $0.10-0.17 \%$, and $0.09-0.15 \%$ to $0.15 \%-0.25 \%$, respectively. With that, with increasing the wavelength, the dispersion of SBC indicators increases. They are less expressed in the plots with good vegetation cover (Figure 2, B), and more pronounced in degraded pastures, especially in the plots with failure (Figure 2, A), which allows to reliably define the boundaries of the pasture degradation degrees.

\section{CONCLUSION}

1. The field soil-and-geobotanical studies of the desert pastures of Southern Balkhash allowed to determine the particularities of forming the soil and vegetation cover and the effect of their long-term systemless use on their degradation that decreased radially within $5 \mathrm{~km}$ from the settlement. 


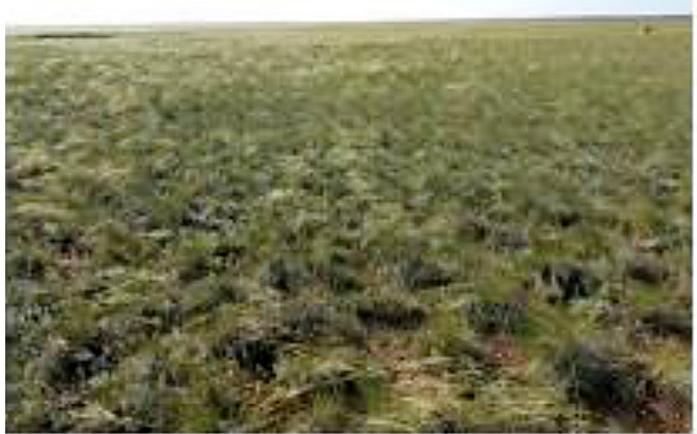

A

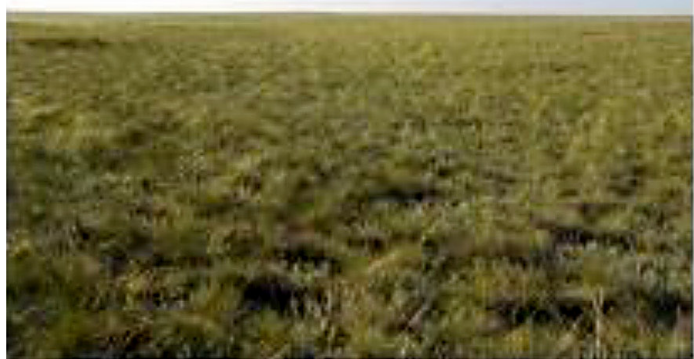

B

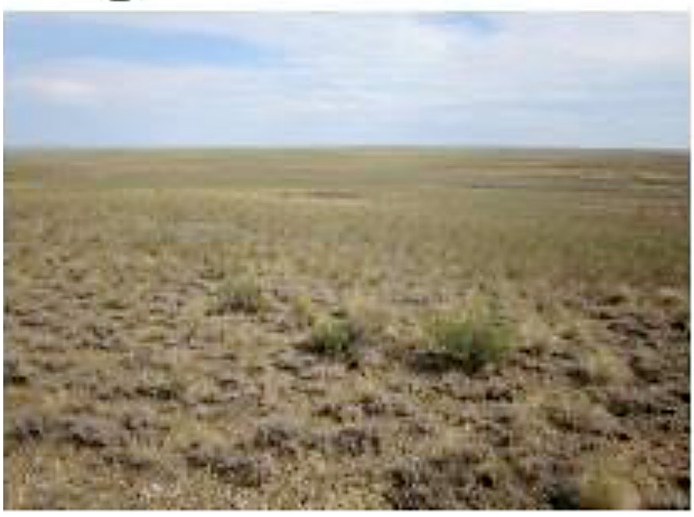

C

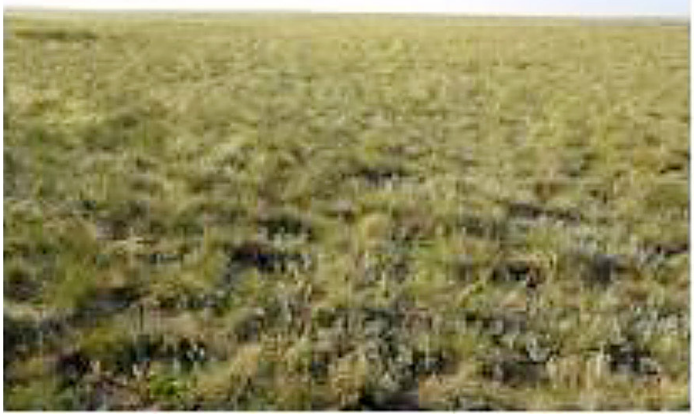

$\mathrm{D}$

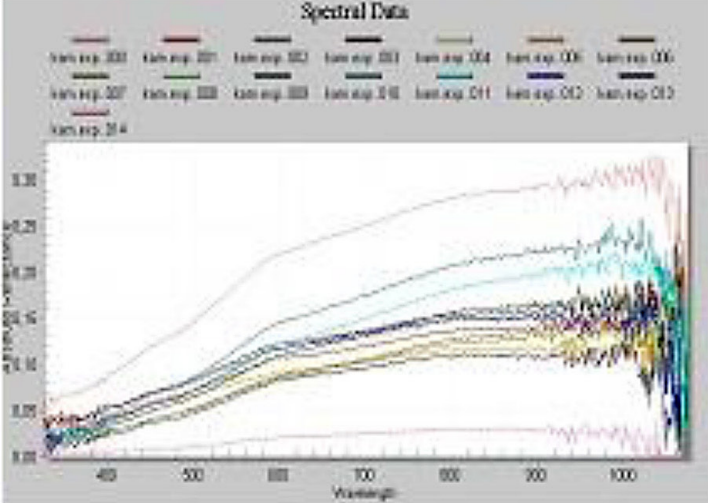

Spetal Luts
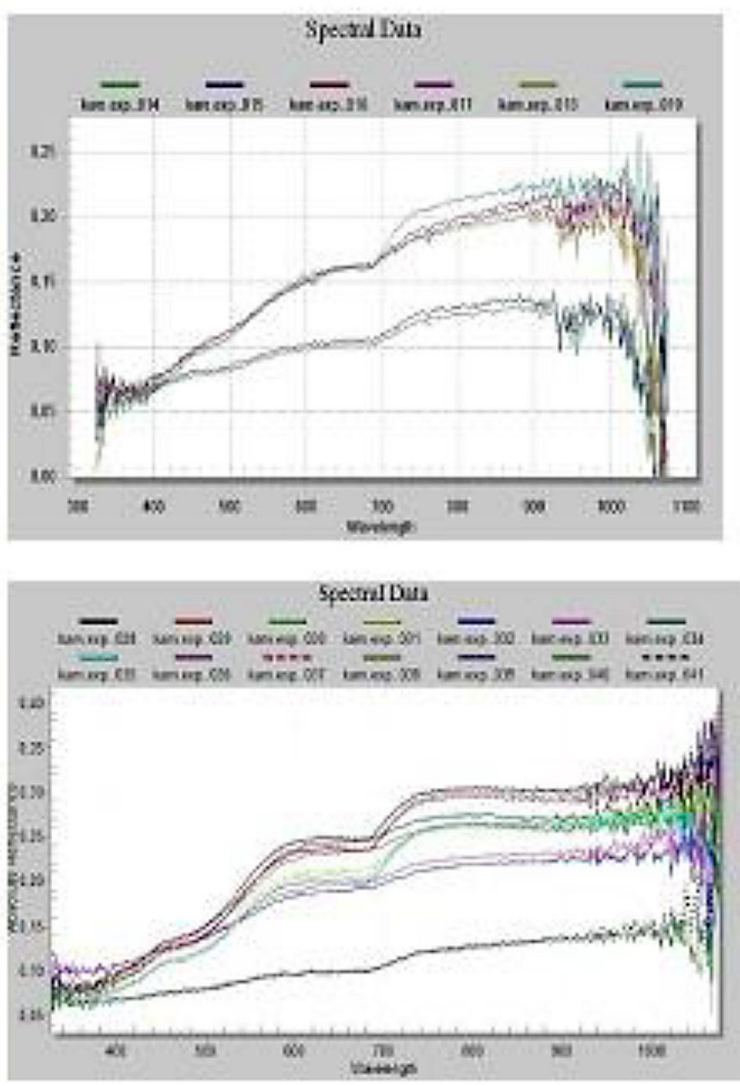

Sotcten Duts

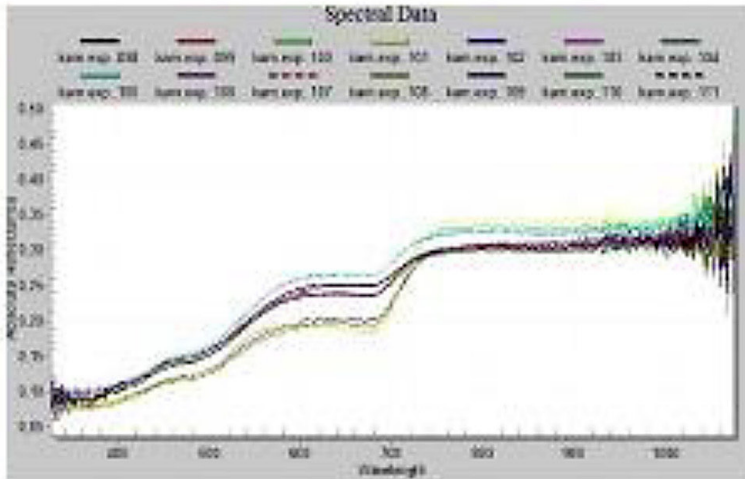

Figure 1. The view of the surfaces of pastures of varying degrees of degradation (left) and their spectral characteristics (right)

A - very severe degradation of IV degree (failure), B - severe degradation of III degree, $\mathrm{C}$ - average degradation of II degree, and D - weak degradation of I degree (background) 
2. Increasing the degree of pasture degradation results in changing their plant communities from the initial (background) stipa-sagebrushceratocarpus to sagebrush-stipa-ceratocarpus (medium degree), and with their further degradation (severe degree) - to sagebrush-ceratocarpus-stipa, and in case of a failure - to ceratocarpus-sagebrush, i.e., stipa disappears. Pasture degradation reduces the productivity of pasture forage from $0.89 \mathrm{t} / \mathrm{ha}$ (observed in the background plot) to $0.40 \mathrm{t} / \mathrm{ha}$ (in the plot with IV degree of degradation).

3. Degradation of desert pastures is manifested in a decreased thickness of the humus horizon (A+B1) from $27 \mathrm{~cm}$ to $18 \mathrm{~cm}$, compaction of the transitional horizon $\mathrm{B} 1$, reduced humus content in horizon A from $0.66 \%$ for the background plot to $0.39 \%$ for the plot with degradation degree III, and physical clay content from $14.2 \%$ to $10.2 \%$, respectively.

4. The SBC of the pasture surface spectra expressed in the nearest infrared, red and blue bands, reliably determines the boundaries of the areas with different degradation degrees.

\section{REFERENCES}

1. Alimaev I.I., Skopintseva I.B., Basova T.A., Krylova B.S. 2017. Ustoichivoe upravlenie pastbishchnymi resursami Kazakhstana s ispolzovaniem GIS-tekhnologii [Sustainable pasture resources management in Kazakhstan using GIS technologies]. Issues of Geography and Geoecology, Almaty, 2, 64-73.

2. Borovsky V.M. 1989. Ekologiya aridnykh pastbishch mira [Ecology of arid pastures of the world]. In the book: Genezis i melioratsiya pochv Kazakhstana [Genesis and melioration of soils in Kazakhstan]. Alma-Ata, Nauka, 208-221.

3. Faizov K.S. 1980. Pochvy pustynnoi zony Kazakhstana [Soils of the desert zone of Kazakhstan]. Alma-Ata, Nauka.

4. Final report of Kazakhstan on UNCCD project Land Degradation Neutrality, LDN, Ministry of Agriculture of Kazakhstan, Astana, 2018.

5. Guidelines and methods of botanic-forage surveys of grasslands and pastures in the territory of Kazakhstan. Alma-Ata, 1969. 87 p.
6. Instruktsiya po provedeniyu krupnomasshtabnykh izyskanii zemel Respubliki Kazakhstan [Guidelines for large-scale land surveys in the Republic of Kazakhstan] 1995. Almaty, 115 p.

7. Karmanov I.I. 1974. Spektralnaya otrazhatelnaya sposobnost i tsvet pochv kak pokazatel ikh svoistv [Soil spectral reflectance and color as an indicator of soil properties]. Moscow, Kolos.

8. Levitskaya Z.P. 1973. Vodno-fizicheskie svoistva i zapasy produktivnoi vlagi pustynno-pastbishchnoi zony Kazakhstana [Water-physical properties and reserves of productive moisture in the desert-pasture zones of Kazakhstan]. Reference book. Alma-Ata. OVGM Department of the Kazakh Hydrometeorology and Environment Monitoring Agency. The Alma-Ata Hydrometeorological Observatory, 46-51.

9. Lobova E.V. 1960. Pochvy pustynnoi zony SSSR [Soils of the desert zone of the USSR]. Moscow, Publishing House of USSR AS.

10. Strategicheskie mery po borbe s opustynivaniem v Respublike Kazakhstan do 2025 goda [Strategic measures to combat desertification in the Republic of Kazakhstan till 2025]. 2015. Astana, 336.

11. The Law of the Republic of Kazakhstan № 47-IV LRK. 20 February 2017. Available: http://adilet. zan.kz/eng/docs/Z1700000047

12. Torekhanov A.A. 2005. Prirodnye pastbishcha Yugo-vostoka [Natural pastures of the Southeast]. Almaty: Kazakh State Institute of Scientific-Technical Information, 203 p;

13. UNDP/GM SGP/GEF OF "Farmer of Kazakhstan". Mobilizatsiya obshchin v Tsentralnoi Azii: Vnedrenie ustoichivogo upravleniya zemelnymi resursami na urovne obshchin i narashchivanie potentsiala mestnogo naseleniya. Mestnye obshchiny $\mathrm{v}$ borbe $\mathrm{s}$ degradatsiei pastbishch [Mobilization of communities in Central Asia: Introduction of sustainable land management at the level of communities and building the potential of local population. Local communities in combating the degradation of pastures]. Almaty, 2007.

14. Zakarin E.A., Spivak L.F., Arkhipkin O.P., Muratova N.R., Terekhov A.G. 1999. Metody distantsionnogo zondirovaniya $\mathrm{v}$ selskom khozyaistve Kazakhstana [Remote sensing methods in the agriculture of Kazakhstan]. Almaty, Gylym.

15. Zhambakin J.A. 1995. Pastbishcha Kazakhstana [Pastures of Kazakhstan]. Almaty, Publishing house Kaynar. 